\title{
Adjuvant endocrine therapy in pre- versus postmenopausal patients with steroid hormone receptor-positive breast cancer: results from a large population-based cohort of a cancer registry
}

\author{
E. C. Inwald ${ }^{1} \cdot$ M. Koller ${ }^{2} \cdot$ M. Klinkhammer-Schalke ${ }^{3} \cdot$ F. Zeman ${ }^{2} \cdot$ F. Hofstädter ${ }^{4}$. \\ P. Lindberg ${ }^{3} \cdot$ M. Gerstenhauer ${ }^{3} \cdot$ S. Schüler ${ }^{1} \cdot$ O. Treeck ${ }^{1} \cdot$ O. Ortmann $^{1}$
}

Received: 14 June 2015 / Accepted: 27 July 2015 / Published online: 8 August 2015

(C) The Author(s) 2015. This article is published with open access at Springerlink.com

\begin{abstract}
Purpose Adjuvant endocrine therapy (ET) is indicated in patients with steroid hormone receptor (HR)-positive breast cancer. The aim of this study was to evaluate the quality of HR determination and adjuvant endocrine treatment of breast cancer patients in a large cohort of more than 7000 women by analyzing data from a population-based regional cancer registry.

Methods Data from the Clinical Cancer Registry Regensburg (Bavaria, Germany) were analyzed. Female patients with primary, nonmetastatic invasive breast cancer who were diagnosed between 2000 and $2012(n=7421)$ were included. HR-status was available in $97.4 \%(n=7229)$ of the patients. This data set $(n=7229)$ was used for subsequent statistical analyses.

Results Since 2009, almost a complete rate of $99.6 \%$ of analyzed HR-status was achieved. In sum, $85.8 \%$ of the
\end{abstract}

E. C. Inwald

Elisabeth.Inwald@ukr.de

M. Koller

Michael.Koller@ukr.de

M. Klinkhammer-Schalke

Monika.Klinkhammer-Schalke@ukr.de

F. Zeman

Florian.Zeman@ukr.de

F. Hofstädter

Ferdinand.Hofstaedter@ukr.de

P. Lindberg

Patricia.Lindberg@ukr.de

M. Gerstenhauer

Marko.Gerstenhauer@ukr.de

S. Schüler

sschueler@caritasstjosef.de patients $(n=6199)$ were HR-positive, whereas $14.2 \%$ $(n=1030)$ were HR-negative. Overall, $85.3 \%(n=5285)$ of HR-positive patients received ET either alone or in combination with chemotherapy (CHT) and/or trastuzumab. The majority of premenopausal patients received CHT plus ET (716 patients, $52.3 \%$ ). In postmenopausal patients, the most frequent systemic therapy was ET alone (2670 patients, $55.3 \%$ ). Best overall survival (OS) was found in HER2-/HR-positive patients receiving CHT plus ET plus trastuzumab (7-year OS rate of $97.2 \%$ in premenopausal patients versus $86.9 \%$ in postmenopausal patients). Premenopausal patients had a reduced benefit from additional CHT than postmenopausal patients. Premenopausal patients receiving only ET had a 7-year OS rate of $95.3 \%$ compared to $92.7 \%$ of patients receiving CHT plus ET. In contrast, postmenopausal patients treated with CHT plus ET had a 7-year OS rate of $84.0 \%$ in comparison with

O. Treeck

otreeck@caritasstjosef.de

O. Ortmann

oortmann@caritasstjosef.de

1 Department of Gynecology and Obstetrics, University Medical Center Regensburg, Landshuter Straße 65, 93053 Regensburg, Germany

2 Center for Clinical Studies, University Hospital Regensburg, Franz-Josef-Strauß-Allee 11, 93053 Regensburg, Germany

3 Tumor Center Regensburg e.V., University of Regensburg, Josef-Engert-Straße 9, 93053 Regensburg, Germany

4 Johannes Kepler University Linz, Altenberger Straße 69, 4040 Linz, Austria 
those patients receiving only ET with a 7-year OS rate of $81.7 \%$.

Conclusions Analysis of HR in patients with early breast cancer achieved a very high quality in recent years. The vast majority of HR-positive patients received ET, and this guideline-adherent use improved OS. Inverse effects of the CHT plus ET combination in premenopausal versus postmenopausal patients and a still existing minority of patients not receiving guideline-adherent treatment should be further investigated in future studies.

Keywords Endocrine therapy $\cdot$ Steroid hormone receptor $\cdot$ Breast cancer $\cdot$ Overall survival $\cdot$ Cancer registry

$\begin{array}{ll}\text { Abbreviations } \\ \text { ET } & \text { Endocrine therapy } \\ \text { HR } & \text { Hormone receptor } \\ \text { CHT } & \text { Chemotherapy } \\ \text { ER } & \text { Estrogen receptor } \\ \text { PR } & \text { Progesterone receptor } \\ \text { AIs } & \text { Aromatase inhibitors } \\ \text { OS } & \text { Overall survival } \\ \text { GnRH } & \text { Gonadotropin-releasing hormone } \\ \text { RCTs } & \text { Randomized controlled trials } \\ \text { IRS } & \text { Immunoreactive score } \\ \text { SD } & \text { Standard deviation } \\ \text { CI } & \text { Confidence interval }\end{array}$

\section{Introduction}

In addition to surgery and irradiation as local therapies, almost all patients with early breast cancer receive adjuvant systemic medical treatments. These may include three components: chemotherapy (CHT), endocrine therapy (ET), and antibody therapy. Provided that breast cancer tissue expresses estrogen (ER) and/or progesterone (PR) receptors, adjuvant ET is indicated (Melcher et al. 2012). Adjuvant treatment with tamoxifen or aromatase inhibitors (AIs) leads to a reduction in both recurrence-free and overall survival (OS) (Early Breast Cancer Trialists' Collaborative Group (EBCTCG) et al. 2005; Baum et al. 2002; Thürlimann et al. 2005). Current state of the art treatment for women with endocrine-responsive early breast cancer is an adjuvant ET for at least 5 years (Kreienberg et al. 2013; Untch et al. 2013; Lux et al. 2013). The type of ET depends on ovarian function. For premenopausal patients, the standard ET is 5 years of tamoxifen monotherapy (EBCTCG et al. 2005). A meta-analysis of the EBCTCG showed efficacy of adjuvant tamoxifen for both pre- and postmenopausal patients (EBCTCG et al. 2011). A further treatment option for premenopausal patients is the combination of tamoxifen with gonadotropin-releasing hormone $(\mathrm{GnRH})$ analogs (Baum et al. 2006; Cuzick et al. 2007). Another approach in premenopausal women is ovarian function suppression combined with AIs, which was investigated in two recently published studies, the suppression of ovarian function trial (SOFT) and tamoxifen and exemestan trial (TEXT) trial (Pagani et al. 2014). Adjuvant treatment with exemestane plus ovarian suppression significantly reduced recurrence in premenopausal patients with HR-positive early breast cancer, as compared with tamoxifen plus ovarian suppression (Pagani et al. 2014).

Large-scale randomized controlled trials (RCTs) investigated the use of AIs as either a substitute or add-on to tamoxifen and showed a superiority of the AIs over tamoxifen in postmenopausal patients (Baum et al. 2002; Thürlimann et al. 2009; Coombes et al. 2004; Goss et al. 2003; Dowsett et al. 2010). Different strategies including AIs are possible, e.g., upfront monotherapy or switch to an AI after 2-3 years of tamoxifen or switch to tamoxifen after 2-3 years of AIs, and extended adjuvant treatment with an AI after 5 years of tamoxifen (Lux et al. 2013; Kolberg et al. 2012). Currently, the prolongation of ET beyond 5 years is discussed. The adjuvant tamoxifen: longer against shorter trial (ATLAS) showed that for ERpositive breast cancer patients continuing tamoxifen for up to 10 years rather than stopping at 5 years yielded a further reduction in recurrence and mortality, particularly after year 10 (Davies et al. 2013). A meta-analysis involving 29,138 patients and eight RCTs concluded that in ER-positive breast cancer patients extended ET beyond 5 years of tamoxifen significantly improved OS [OR $0.89 ; 95 \%$ confidence interval (CI) $0.80-0.99 ; P=0.03$ ], breast cancerspecific survival (OR 0.78; $95 \%$ CI 0.69-0.9; $P=0.0003$ ), and relapse-free survival (OR 0.72; $95 \%$ CI 0.56-0.92; $P=0.01$ ) compared with 5 years of ET alone (Petrelli et al. 2013). However, further follow-up of the included trials is needed to confirm these results.

Despite these encouraging findings from numerous RCTs and meta-analyses, data on the performance of ET under routine conditions are scarce. Thus, the aim of this study was to evaluate the routine quality of diagnosis and adjuvant endocrine treatment of steroid hormone receptor (HR)-positive breast cancer patients in a large cohort of more than 7000 patients by analyzing data from a population-based regional cancer registry.

\section{Methods}

\section{Database}

In the present study, data from the Tumor Center Regensburg (Bavaria, Germany) were analyzed. This high-quality population-based regional cancer registry was founded 
in 1991 and covers a population of more than 2.2 million people of Upper Palatinate and Lower Bavaria. Currently, follow-up data of 240,655 patients of all major cancer sites are available. Following a stringent protocol, this cancer registry obtains a cross-sectorial documentation of all breast cancer patients in the area $(n=10,152$ patients diagnosed between 2000 and 2012). Information about diagnosis, course of disease, therapies, and long-term follow-up are documented. Patient data originate from the University Hospital Regensburg, 53 regional hospitals, and more than 1000 practicing doctors in the region. Based on medical reports, pathology, and follow-up records, these population-based data are routinely being documented and fed into the cancer registry.

\section{Cancer registration in Bavaria}

In Bavaria, the law on the Bavarian Epidemiologic Cancer Registry (Gesetz über das bevölkerungsbezogene Krebsregister Bayern-BayKRG, as amended from time to time) allows the continuous and uniform data acquisition and processing of cancer incidences by means of an epidemiologic cancer registry. The purpose of this law is to regulate cancer control and to improve data quality of cancer epidemiology. The Bavarian Epidemiologic Cancer Registry has to provide anonymous data for scientific research.

Informed consent has to be given in accordance with the Declaration of Helsinki and is an indispensable precondition for data storage. Any physician has to adequately inform the patients about the intended or performed transmission of data to the registry. Patients also receive written information about these procedures. Each patient has the right to object data storage at any time. On the basis of this law, retrospective analyses of anonymous data require no additional ethics statement.

\section{Inclusion and exclusion criteria}

The present analysis included all female patients documented in the cancer registry with primary, nonmetastatic (M0) invasive breast cancer diagnosed between January 2000 and December 2012 (13 years). Follow-up data up to July 2013 were analyzed. Exclusion criteria were male patients, ductal carcinoma in situ (DCIS), and distant metastases (Fig. 1).

\section{Analysis of $\mathbf{H R}$}

Immunohistochemical determination of ER and PR was performed and quantified as the percentage of positivity of malignant cells and average intensity of coloration consistent with defined standards (Prechtel and Prechtel 2001).

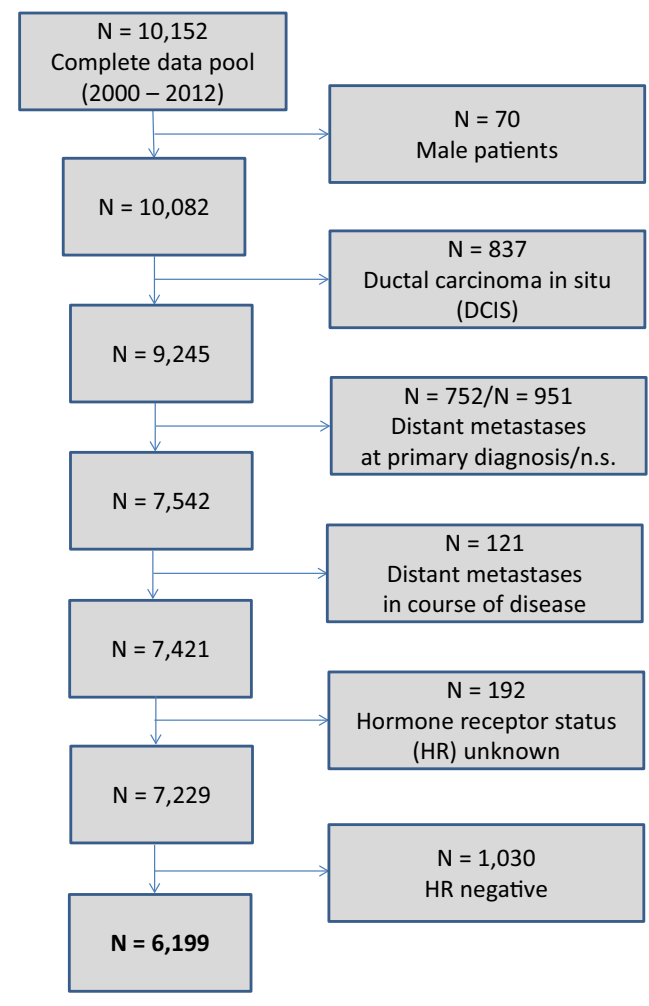

Fig. 1 Scheme of data extraction

Additionally, the immunoreactive score (IRS) according to Remmele and Stegner (1987) was calculated. In the last update of the German interdisciplinary S3 Guideline for Diagnosis, Treatment and Follow-up Care of Breast Cancer (updated version 07/2012, registry number 032045OL of Association of the Scientific Medical Societies, AWMF) (Kreienberg et al. 2013), cutoff definitions for the interpretation of results were modified and follow the current ASCO/CAP recommendations (Hammond et al. 2010). Since that date, at least $1 \%$ of positively marking malignant cells is sufficient for determination of HR-status as positive. Previously, at least $10 \%$ positivity was necessary. In the data set, HR-positivity is defined as ER+PR+, $\mathrm{ER}+\mathrm{PR}-$ or ER-PR+. HR-negativity is defined as $\mathrm{ER}-\mathrm{PR}-$.

\section{Quality assurance methods}

Overall, six institutes of pathology were involved in these analyses. Consistency and quality control are ensured through various quality assurance methods including the certification/accreditation of the pathologies according to DIN EN ISO 9001, the participation in the German interlaboratory trials, and regular regional breast cancer-specific quality assurance conferences (Inwald et al. 2013). 
Table 1 Time-dependent rates of hormone receptor (HR) analyses

\begin{tabular}{lccccc}
\hline Year of diagnosis & $\begin{array}{l}\text { Number of } \\
\text { patients }(n)\end{array}$ & $\begin{array}{l}\text { HR-status } \\
\text { unknown }(n, \%)\end{array}$ & $\begin{array}{l}\text { HR-status analyzed } \\
(n, \%)\end{array}$ & HR-positive $(n, \%)$ & HR-negative $(n, \%)$ \\
\hline 2000 & 448 & $28(6.3 \%)$ & $420(93.7 \%)$ & $345(82.1 \%)$ & $75(17.9 \%)$ \\
2001 & 472 & $16(3.4 \%)$ & $456(96.6 \%)$ & $401(87.9 \%)$ & $55(12.1 \%)$ \\
2002 & 477 & $19(4.0 \%)$ & $458(96.0 \%)$ & $379(82.8 \%)$ & $79(17.2 \%)$ \\
2003 & 536 & $10(1.9 \%)$ & $526(98.1 \%)$ & $466(88.6 \%)$ & $60(11.4 \%)$ \\
2004 & 595 & $20(3.4 \%)$ & $575(96.6 \%)$ & $489(85.0 \%)$ & $86(15.0 \%)$ \\
2005 & 585 & $8(1.4 \%)$ & $577(98.6 \%)$ & $471(81.6 \%)$ & $106(18.4 \%)$ \\
2006 & 570 & $1(0.2 \%)$ & $569(99.8 \%)$ & $487(85.6 \%)$ & $82(14.4 \%)$ \\
2007 & 603 & $34(5.6 \%)$ & $569(94.4 \%)$ & $492(86.5 \%)$ & $77(13.5 \%)$ \\
2008 & 608 & $45(7.4 \%)$ & $563(92.6 \%)$ & $464(82.4 \%)$ & $99(17.6 \%)$ \\
2009 & 721 & $3(0.4 \%)$ & $718(99.6 \%)$ & $624(86.9 \%)$ & $94(13.1 \%)$ \\
2010 & 628 & $4(0.6 \%)$ & $624(99.4 \%)$ & $542(86.9 \%)$ & $82(13.1 \%)$ \\
2011 & 579 & $2(0.3 \%)$ & $577(99.7 \%)$ & $513(88.9 \%)$ & $64(11.1 \%)$ \\
2012 & 599 & $2(0.3 \%)$ & $597(99.7 \%)$ & $526(88.1 \%)$ & $71(11.9 \%)$ \\
Total & 7421 & $192(2.6 \%)$ & $7229(97.4 \%)$ & $6199(85.8 \%)$ & $1030(14.2 \%)$ \\
\hline
\end{tabular}

HR-positive is defined as $\mathrm{ER}+\mathrm{PR}+, \mathrm{ER}+\mathrm{PR}-$, or $\mathrm{ER}-\mathrm{PR}+$

HR-negative is defined as ER-PR-

\section{Statistical analyses}

Continuous data were expressed as means \pm standard deviations (SD) and categorical data as frequency counts and percentages. Baseline characteristics of patients were compared between HR-status by Student's $t$ test for continuous variables and by Pearson's Chi-square tests for categorical variables. OS was calculated from the date of cancer diagnosis to the date of death from any cause. Patients who were not dead or patients without follow-up were classified as censored. The impact of established prognostic factors (age, tumor size, nodal status, grading, HER2/neu, and menopausal status) and the extent of primary therapy on OS were assessed by means of a multivariable Cox regression analysis. Hazard ratios $(H R)$ and corresponding $95 \%$ $\mathrm{CI}$ were calculated and considered statistically significant if CI excluded 1.0. All reported $P$ values were two-sided, and a $P$ value of 0.05 was considered the threshold of statistical significance. Calculations were made with the software packages SPSS 22 (Chicago, EUA) and R (version 3.0.3).

\section{Results}

\section{Analysis of patients' characteristics}

According to the ICD-10 classification, 7421 female patients with invasive, nonmetastatic breast cancer (C50) were extracted from the total data pool of breast tumor patients (Fig. 1). The HR-status was available in $97.4 \%$ (7229 patients) (Table 1). In $2.6 \%$ (192 patients), the
HR-status was absent due to missing information in the medical reports or no analysis. Since 2009, almost a complete rate of $99.6 \%$ of analyzed HR-status was achieved. Only patients with noted HR-status were included for further statistical evaluation. Hence, a total of 7229 breast cancer patients were considered for subsequent analyses (Table 2). In total, 1684 patients $(23.3 \%)$ were premenopausal and 5545 patients $(76.7 \%)$ were postmenopausal. Mean age was 61 years (median 61 years, range 21-97 years); $85.8 \%$ of patients $(n=6199)$ were HRpositive, whereas $14.2 \%$ of patients $(n=1030)$ were HR-negative. Postmenopausal women were more likely to be HR-positive $(n=4830,87.1 \%)$ than premenopausal patients $(n=1369,81.3 \%)$. All common histopathological parameters showed (highly) statistically significant differences between HR-positive and HR-negative patients. High-grade (G3) tumors were rather associated with negative HR-status. In HR-negative patients, $73.0 \%$ of tumors were high grade compared to $20.2 \%$ of HR-positive tumors $(P<0.001)$. HR-positive patients were more likely to be HER2-negative $(75.5 \%)$ than HR-negative patients $(60.6 \%)(P<0.001)$ (Table 2). Detailed description of HRstatus is shown in Table 3. The majority of patients were both ER- and PR-positive (73.9 \%) in both premenopausal and postmenopausal patients.

\section{Distribution of HR-status across different pathologies}

To evaluate the inter-laboratory consistency, we investigated the distribution of patients in different institutes of pathology as well as the distribution of HR-status. A total 
Table 2 Associations between HR and clinical and histopathological parameters

\begin{tabular}{|c|c|c|c|c|}
\hline Parameter & HR-positive $(n=6199)$ & HR-negative $(n=1030)$ & Total $(n=7229)$ & $P$ value $^{\mathrm{a}}$ \\
\hline Age (year), mean $\pm \mathrm{SD}$ & $62 \pm 13$ & $57 \pm 14$ & $61 \pm 13$ & $<0.001$ \\
\hline \multicolumn{5}{|l|}{ Menopausal state, $n(\%)$} \\
\hline Premenopausal & $1369(22.1 \%)$ & $315(30.6 \%)$ & $1684(23.3 \%)$ & \multirow[t]{2}{*}{$<0.001$} \\
\hline Postmenopausal & $4830(77.9 \%)$ & $715(69.4 \%)$ & $5545(76.7 \%)$ & \\
\hline \multicolumn{5}{|l|}{ Histology, $n(\%)$} \\
\hline Ductal & $4913(79.3 \%)$ & $896(87.0 \%)$ & $5809(80.4 \%)$ & \multirow[t]{3}{*}{$<0.001$} \\
\hline Lobular & $876(14.1 \%)$ & $28(2.7 \%)$ & $904(12.5 \%)$ & \\
\hline Other & $410(6.6 \%)$ & $106(10.3 \%)$ & $516(7.1 \%)$ & \\
\hline \multicolumn{5}{|l|}{ Tumor size, $n(\%)$} \\
\hline pT0 & $27(0.4 \%)$ & $31(3.0 \%)$ & $58(0.8 \%)$ & \multirow[t]{6}{*}{$<0.001$} \\
\hline pT1 & $3385(54.6 \%)$ & $435(42.2 \%)$ & $3820(52.8 \%)$ & \\
\hline pT2 & $2217(35.8 \%)$ & $449(43.6 \%)$ & $2666(36.9 \%)$ & \\
\hline pT3 & $237(3.8 \%)$ & $49(4.8 \%)$ & $286(4.0 \%)$ & \\
\hline pT4 & $301(4.9 \%)$ & $56(5.4 \%)$ & $357(4.9 \%)$ & \\
\hline Unknown & $32(0.5 \%)$ & $10(1.0 \%)$ & $42(0.6 \%)$ & \\
\hline \multicolumn{5}{|l|}{ Nodal status, $n(\%)$} \\
\hline $\mathrm{pNO}$ & $3832(61.8 \%)$ & $608(59.0 \%)$ & $4440(61.4 \%)$ & \multirow[t]{5}{*}{0.032} \\
\hline $\mathrm{pN} 1$ & $1534(24.7 \%)$ & $249(24.2 \%)$ & $1783(24.7 \%)$ & \\
\hline $\mathrm{pN} 2$ & $425(6.9 \%)$ & $93(9.0 \%)$ & $518(7.2 \%)$ & \\
\hline $\mathrm{pN} 3$ & $283(4.6 \%)$ & $57(5.5 \%)$ & $340(4.7 \%)$ & \\
\hline Unknown & $125(2.0 \%)$ & $23(2.2 \%)$ & $148(2.0 \%)$ & \\
\hline \multicolumn{5}{|l|}{ Grading, $n(\%)$} \\
\hline G1 & $1017(16.4 \%)$ & $14(1.4 \%)$ & $1031(14.3 \%)$ & \multirow[t]{4}{*}{$<0.001$} \\
\hline $\mathrm{G} 2$ & $3891(62.8 \%)$ & $256(24.9 \%)$ & $4147(57.4 \%)$ & \\
\hline G3 & $1252(20.2 \%)$ & $752(73.0 \%)$ & $2004(27.7 \%)$ & \\
\hline Unknown & $39(0.6 \%)$ & $8(0.8 \%)$ & $47(0.7 \%)$ & \\
\hline \multicolumn{5}{|l|}{ HER2, $n(\%)$} \\
\hline Negative & $4678(75.5 \%)$ & $624(60.6 \%)$ & $5302(73.3 \%)$ & \multirow[t]{3}{*}{$<0.001$} \\
\hline Positive & $952(15.4 \%)$ & $306(29.7 \%)$ & $1258(17.4 \%)$ & \\
\hline Unknown & $569(9.2 \%)$ & $100(9.7 \%)$ & $669(9.3 \%)$ & \\
\hline \multicolumn{5}{|l|}{ Lymphatic invasion, $n(\%)$} \\
\hline Positive & $1676(27.0 \%)$ & $350(34.0 \%)$ & $2026(28.0 \%)$ & \multirow[t]{3}{*}{$<0.001$} \\
\hline Negative & $3024(48.8 \%)$ & $430(41.7 \%)$ & $3454(47.8 \%)$ & \\
\hline Unknown & $1499(24.2 \%)$ & $250(24.3 \%)$ & $1749(24.2 \%)$ & \\
\hline \multicolumn{5}{|l|}{ Vascular invasion, $n(\%)$} \\
\hline Positive & $320(5.2 \%)$ & $92(8.9 \%)$ & $412(5.7 \%)$ & \multirow[t]{3}{*}{$<0.001$} \\
\hline Negative & $4168(67.2 \%)$ & $634(61.6 \%)$ & $4802(66.4 \%)$ & \\
\hline Unknown & $1711(27.6 \%)$ & $304(29.5 \%)$ & $2015(27.9 \%)$ & \\
\hline
\end{tabular}

HR-positive is defined as $\mathrm{ER}+\mathrm{PR}+, \mathrm{ER}+\mathrm{PR}-$, or $\mathrm{ER}-\mathrm{PR}+$

HR-negative is defined as ER-PR-

a $P$ value of $t$ test or Pearson's Chi-square test, respectively

\begin{tabular}{lccc}
\hline & $\begin{array}{l}\text { Premenopausal } \\
(n=1684,23 \%)\end{array}$ & $\begin{array}{c}\text { Postmenopausal } \\
(n=5545,77 \%)\end{array}$ & Total $(n=7229,100 \%)$ \\
\hline ER+PR+ & $1206(71.6 \%)$ & $4137(74.6 \%)$ & $5343(73.9 \%)$ \\
ER+PR - & $125(7.4 \%)$ & $600(10.8 \%)$ & $725(10.0 \%)$ \\
ER-PR+ & $38(2.3 \%)$ & $93(1.7 \%)$ & $131(1.8 \%)$ \\
ER-PR- & $315(18.7 \%)$ & $715(12.9 \%)$ & $1030(14.2 \%)$ \\
\hline
\end{tabular}

Table 3 ER- and/or PR-expression 


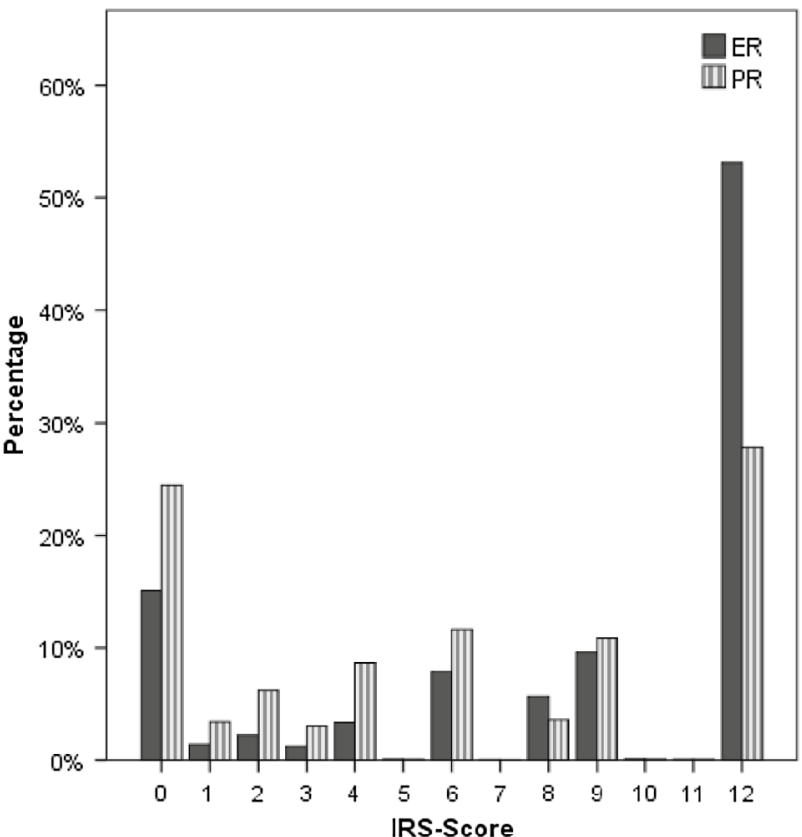

\begin{tabular}{|l|c|c|}
\hline IRS-Score & Estrogen receptor (N, \%) & Progesterone receptor (N,\%) \\
\hline 0 & $826(15 \%)$ & $1324(24 \%)$ \\
\hline 1 & $79(1 \%)$ & $185(3 \%)$ \\
\hline 2 & $123(2 \%)$ & $338(6 \%)$ \\
\hline 3 & $68(1 \%)$ & $165(3 \%)$ \\
\hline 4 & $183(3 \%)$ & $471(9 \%)$ \\
\hline 5 & $5(0 \%)$ & $4(0 \%)$ \\
\hline 6 & $433(8 \%)$ & $631(12 \%)$ \\
\hline 7 & $2(0 \%)$ & $1(0 \%)$ \\
\hline 8 & $310(6 \%)$ & $195(4 \%)$ \\
\hline 9 & $524(10 \%)$ & $587(11 \%)$ \\
\hline 10 & $6(0 \%)$ & $5(0 \%)$ \\
\hline 11 & $4(0 \%)$ & $4(0 \%)$ \\
\hline 12 & $2903(53 \%)$ & $1506(28 \%)$ \\
\hline Total & $5466(100 \%)$ & $5416(100 \%)$ \\
\hline
\end{tabular}

Fig. 2 Distribution of IRS scores of ER and PR

of six institutions were involved in HR diagnostics. These analyzed samples from 133 to 1787 patients. The distribution of HR-status across the different pathologies was homogenous which reflects the established quality assurance methods in the Tumor Centre Regensburg. Regarding ER, $15 \%$ of samples from patients $(n=826)$ had IRS 0 , and $53 \%(n=2903)$ had IRS 12 . With respect to PR, $24 \%$ of patients $(n=1324)$ had IRS 0 , and $28 \%(n=1506)$ had IRS 12. IRSs lying in between were underrepresented (Fig. 2).

\section{Systemic therapies in HR-positive patients}

Overall, 5285 (85.3\%) of 6199 HR-positive patients received ET either alone or in combination with CHT and/or trastuzumab (Table 4). Thereby, the proportion of premenopausal and postmenopausal patients receiving
ET was identical $(85.8 \%$ premenopausal versus $85.1 \%$ postmenopausal).

The majority of premenopausal patients received CHT plus ET (716 patients, $52.3 \%$ ) and ET alone (343 patients, $25.1 \%$ ), respectively. In postmenopausal patients, the most frequent systemic therapy was ET alone (2670 patients, $55.3 \%$ ) followed by CHT plus ET (1255 patients, $26.0 \%$ ). The relatively large number of 614 HR-positive patients $(9.9 \%)$ received no adjuvant therapy at all (Table 4). Further analyses regarding this revealed the following: In $n=368 / 614$ (59.9\%) of these patients, an ET was planned but not started yet, $n=36(5.9 \%)$ of the patients declined an ET, and in $34.2 \%$ of the cases, reasons for the nonuse could not be identified.

\section{Analysis of type of ET in HR-positive patients}

Moreover, the type of ET in HR-positive patients was analyzed (Table 5). In $85.2 \%$ of patients $(n=4504)$, the type of ET was documented. In pre- and in postmenopausal patients, the most frequently applied ET was tamoxifen $(66.8 \%, n=666$ premenopausal versus $50.5 \%, n=1770$ postmenopausal patients). Furthermore, $20.0 \%(n=199)$ of premenopausal patients obtained tamoxifen plus GnRH and $8.7 \%(n=87)$ AIs alone. In sum, $46.3 \%(n=1625)$ of the postmenopausal patients received AIs alone. Overall, $2.5 \%(n=112)$ of patients were treated with tamoxifen followed by AI.

\section{Survival analyses in HR-positive patients}

To evaluate the effects of various systemic therapies, we compared the different treatment groups (Table 6). Premenopausal patients generally showed better survival rates than postmenopausal patients. Best OS was found in HER2-/HR-positive patients receiving CHT plus ET plus trastuzumab in premenopausal as well as in postmenopausal patients (7-year OS rate of $97.2 \%$ in premenopausal patients versus $86.9 \%$ in postmenopausal patients). The effect of the (non-) use of trastuzumab on survival in HER2-positive breast cancer patients and its correlation with HR-status and ET has been previously shown in a study of our group in the same patient cohort (Inwald et al. 2014). In HER2-positive patients $(n=1258)$, there was a significant difference in OS between HR-positive and HR-negative patients (7-year OS rate of $83.7 \%$ in HRpositive patients versus $76.0 \%$ in HR-negative patients, $P=0.006)$.

\section{Survival effects as a function of menopausal state}

Application of CHT prior to ET led to different survival effects in both age groups (Figs. 3, 4). Premenopausal 
Table 4 Different systemic therapies in HR-positive patients
Table 5 Type of ET in HR-positive patients

Table 6 Overall survival rates categorized by menopausal status and adjuvant therapy

\begin{tabular}{lccc}
\hline & $\begin{array}{l}\text { Premenopausal } \\
(n=1369,22.1 \%)\end{array}$ & $\begin{array}{l}\text { Postmenopausal } \\
(n=4830,77.9 \%)\end{array}$ & Total $(n=6199,100 \%)$ \\
\hline $\begin{array}{l}\text { CHT + ET + Trastu- } \\
\text { zumab }\end{array}$ & $115(8.4 \%)$ & $170(3.5 \%)$ & $285(4.6 \%)$ \\
CHT + Trastuzumab & $14(1.0 \%)$ & $18(0.4 \%)$ & $32(0.5 \%)$ \\
ET + Trastuzumab & $1(0.1 \%)$ & $15(0.3 \%)$ & $16(0.3 \%)$ \\
CHT + ET & $716(52.3 \%)$ & $1255(26.0 \%)$ & $1971(31.8 \%)$ \\
ET & $343(25.1 \%)$ & $2670(55.3 \%)$ & $3013(48.6 \%)$ \\
CHT & $96(7.0 \%)$ & $172(3.6 \%)$ & $268(4.3 \%)$ \\
No adjuvant therapy & $84(6.1 \%)$ & $530(11.0 \%)$ & $614(9.9 \%)$ \\
\hline
\end{tabular}

\begin{tabular}{llcc}
\hline & $\begin{array}{l}\text { Premenopausal } \\
(n=1175,22.2 \%)\end{array}$ & $\begin{array}{l}\text { Postmenopausal } \\
(n=4110,77.8 \%)\end{array}$ & Total $(n=5285,100 \%)$ \\
\hline Unknown & $178(15.1 \%)$ & $603(14.7 \%)$ & $781(14.8 \%)$ \\
Known & $997(84.9 \%)$ & $3507(85.3 \%)$ & $4504(85.2 \%)$ \\
Tamoxifen & $666(66.8 \%)$ & $1770(50.5 \%)$ & $2436(54.1 \%)$ \\
Tamox- & $199(20.0 \%)$ & $14(0.4 \%)$ & $213(4.7 \%)$ \\
$\quad$ ifen + GnRH & & & $112(2.5 \%)$ \\
Tamoxifen + AI & $14(1.4 \%)$ & $98(2.8 \%)$ & $1712(38.0 \%)$ \\
AI & $87(8.7 \%)$ & $1625(46.3 \%)$ & $31(0.7 \%)$ \\
GnRH & $31(3.1 \%)$ & - & \\
\hline
\end{tabular}

\begin{tabular}{lllll}
\hline & $\begin{array}{l}3 \text {-Year OS } \\
(\%)\end{array}$ & $\begin{array}{l}5 \text {-Year OS } \\
(\%)\end{array}$ & $\begin{array}{l}6 \text {-Year OS } \\
(\%)\end{array}$ & $\begin{array}{l}7 \text {-Year OS } \\
(\%)\end{array}$ \\
\hline CHT + ET + Trastuzumab & & & & \\
$\quad$ Premenopausal $(n=115,8.5 \%)$ & 98.9 & 97.2 & 97.2 & 97.2 \\
Postmenopausal $(n=170,3.5 \%)$ & 96.6 & 93.1 & 93.1 & 86.9 \\
CHT + ET & & & & 92.7 \\
Premenopausal $(n=716,52.9 \%)$ & 97.1 & 95.6 & 94.5 & 84.5 \\
Postmenopausal $(n=1255,26.2 \%)$ & 95.9 & 89.9 & 87.0 & 95.3 \\
ET & & & & 81.7 \\
Premenopausal $(n=343,25.3 \%)$ & 99.0 & 96.9 & 96.5 & 77.6 \\
Postmenopausal $(n=2670,55.7 \%)$ & 93.9 & 87.8 & 84.8 & 72.4 \\
CHT & & & 77.6 & \\
Premenopausal $(n=96,7.1 \%)$ & 92.7 & 83.7 & 74.9 & 73.1 \\
Postmenopausal $(n=172,3.6 \%)$ & 80.5 & 75.9 & 73.1 & 58.9 \\
No adjuvant therapy & & & 63.5 & \\
Premenopausal $(n=84,6.2 \%)$ & 94.1 & 90.8 & 68.8 & \\
Postmenopausal $(n=530,11.0 \%)$ & 79.2 &
\end{tabular}

Premenopausal patients: $n=1354$

Postmenopausal patients: $n=4797$

Total: $n=6151$

patients (Fig. 3) had a reduced benefit from additional CHT than postmenopausal patients (Fig. 4). Premenopausal patients receiving only ET had a 7-year OS rate of $95.3 \%$ compared to $92.7 \%$ of patients receiving CHT plus ET. In contrast, postmenopausal patients treated with
CHT plus ET had a 7-year OS rate of $84.0 \%$ in comparison with those patients receiving only ET with a 7-year OS rate of $81.7 \%$. Depriving HR-positive patients ET and only administering CHT caused lower OS rates in both age groups than in the particular control group. Lowest OS of 


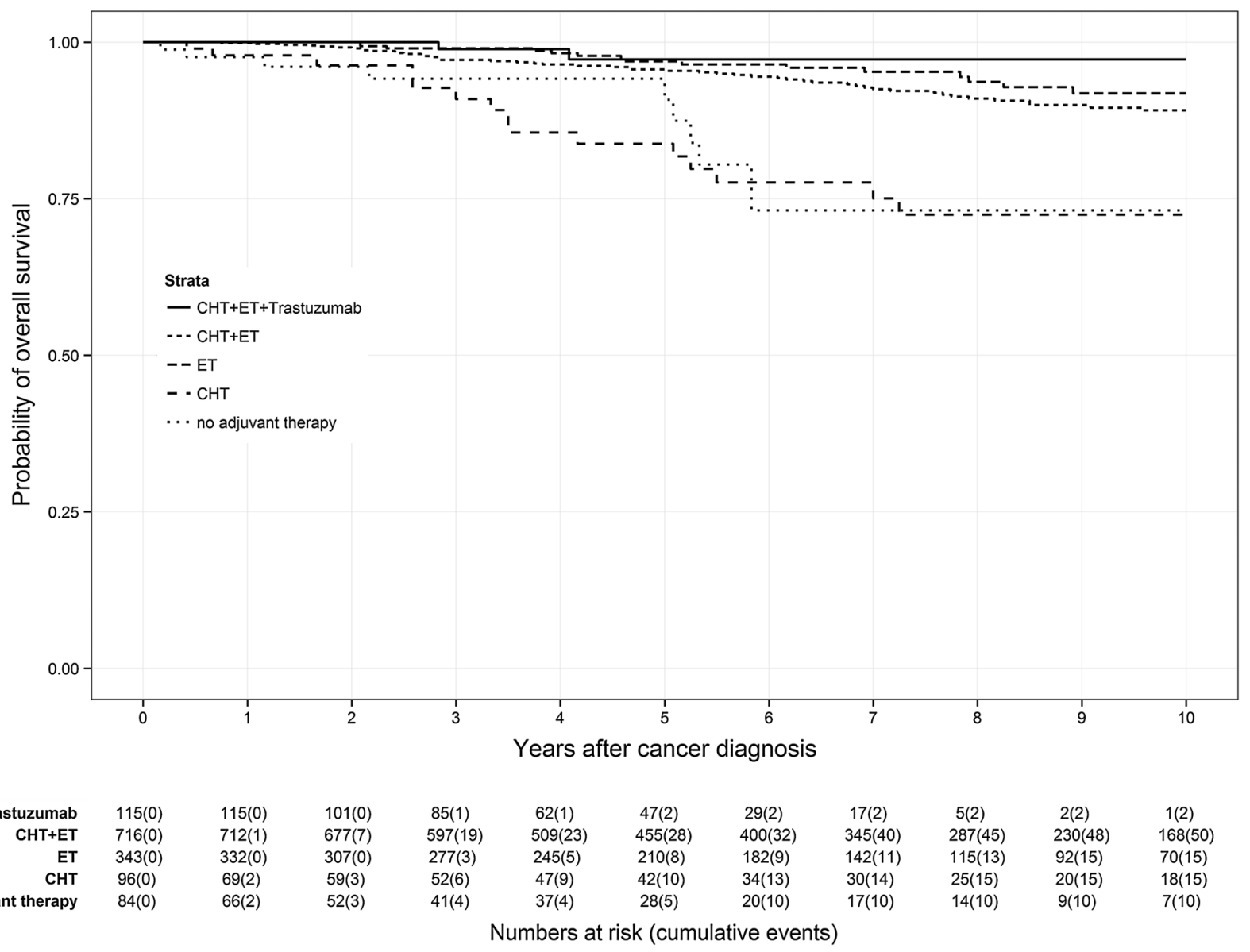

Fig. 3 Kaplan-Meier plot of overall survival in years of premenopausal patients based on adjuvant therapy

HR-positive patients was found in patients receiving no adjuvant therapy at all with a 7-year OS rate of $73.1 \%$ in premenopausal patients and $58.9 \%$ in postmenopausal patients.

A Cox regression model (Table 7) provided further evidence that HR-positive patients ( $n=5410,705$ events) without ET showed lower OS than the control groups. Patients without ET but only CHT (HR 4.54, 95 \% CI 2.29-9.00, $P<0.001)$ and patients receiving no adjuvant therapy at all (HR 4.69, $95 \%$ CI 2.43-9.06, $P<0.001)$ had the lowest OS.

\section{Discussion}

National and international guidelines strongly recommend the determination of HR-status in all patients with invasive breast cancer (Kreienberg et al. 2013; Untch et al. 2013). In HR-positive early breast cancer, adjuvant ET is considered as standard care. Using data from a high-quality population-based regional cancer registry, we were able to analyze the quality of routine care.
HR determination steadily increased from $93.7 \%$ in 2000 to $99.7 \%$ in 2012 and from 2009 on reached a constant peak of $99.6 \%$. This demonstrates the high quality of HR assessment in the investigated area. Concerning HR-status, a slight increase in HR-positive breast cancer was observed from $82.1 \%$ in 2000 to $88.1 \%$ in 2012 . In HR-positive breast cancer, the most common type was both ER- and PR-positive tumors with $71.6 \%$ in premenopausal patients and $74.6 \%$ in postmenopausal patients. Interlaboratory consistency between the pathologies was given as the HR-status displayed to be homogenous. This fact can be expressed through the established quality assurance methods in the Tumor Centre Regensburg. The majority of breast cancers were scored as IRS 0 and IRS 12, whereas the IRSs lying in between were underrepresented in both ER and PR analyses. This distribution of IRS might be a function of tumor biology. In total, $73.9 \%$ of patients were $\mathrm{ER}+\mathrm{PR}+$ which represent Luminal A patients regarding the biology of tumors. These patients usually show high expression of ER and PR. By contrast, triplenegative tumors, i.e., basal-like tumors, are characterized by HR-negativity, defined as ER-PR-. In total, $14.2 \%$ 


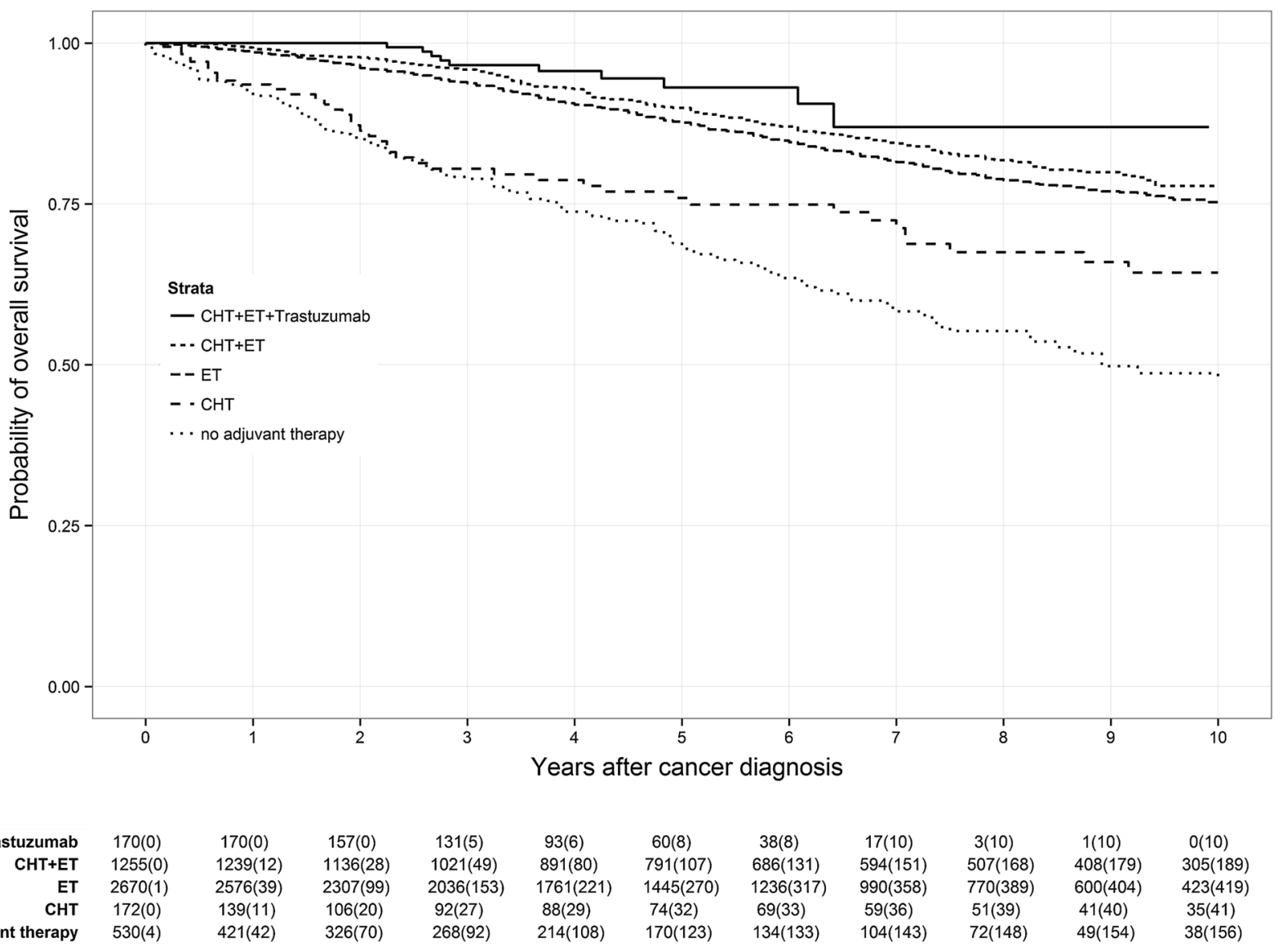

Numbers at risk (cumulative events)

Fig. 4 Kaplan-Meier plot of overall survival in years of postmenopausal patients based on adjuvant therapy

of our patients belong to this group. Analysis of systemic therapies showed that $85.3 \%$ of all HR-positive patients received ET either alone or in combination with CHT and/ or trastuzumab which is in accordance with prior analyses of clinical cohort studies (Van Ewijk et al. 2013). However, nearly $10 \%$ of HR-positive patients did not receive adjuvant therapy. This finding is comparable to data from a longitudinal study of breast cancer patients reported to the Metropolitan Detroit and Los Angeles SEER cancer registries: Of the 743 patients eligible for ET, $10.8 \%$ never initiated therapy and $15.1 \%$ started therapy but discontinued prematurely (Friese et al. 2013). Up to $5 \%$ of HR-positive patients did not receive ET but only CHT. This might be due to lacking compliance of these patients. Generally, adjuvant therapy begins with CHT followed by ET. Presumably, these patients declined ET as they had to suffer from many side effects from CHT. They might worry about further side effects from ET and the long duration of therapy.

The most frequently applied form of systemic treatment was a combination of CHT and ET in premenopausal and
ET alone in postmenopausal patients. However, only postmenopausal patients had a distinct benefit from the addition of CHT prior to ET. The Oxford Overview (Pritchard et al. 2012) similarly showed that there was a trend suggesting greater CHT effect in the age 55- to 69-year group than in younger women. A Danish study from the population-based database of the Danish Breast Cancer Cooperative Group evaluated 6529 postmenopausal patients with ER-positive high-risk breast cancer and also concluded that only one quarter of postmenopausal patients are free of excess mortality when omitting adjuvant CHT (Ejlertsen et al. 2014). A 10-year update of the International Breast Cancer Study Group (IBCSG) Trial 11-93 demonstrated no evidence that adjuvant CHT provides additional disease control for premenopausal patients with lower-risk nodepositive endocrine-responsive breast cancer who receive adequate adjuvant ET (Thürlimann et al. 2009). The reasons for these therapy effects in different age groups are probably multifactorial. A possible explanation might be a bias of selected therapies. It can be presumed that only patients without comorbidities, which are found more often 
Table 7 Multivariable Cox proportional hazard model on overall survival

\begin{tabular}{|c|c|c|c|}
\hline \multirow[t]{2}{*}{ Characteristic } & \multicolumn{3}{|c|}{$\begin{array}{l}\text { Overall survival }(n=5410, \\
\text { events }=705)\end{array}$} \\
\hline & HR & $95 \% \mathrm{CI}$ & $P$ value \\
\hline \multicolumn{4}{|l|}{ Primary therapy } \\
\hline $\mathrm{CHT}+\mathrm{ET}+$ Trastuzumab & Reference & & \\
\hline $\mathrm{CHT}+\mathrm{ET}$ & 1.68 & $0.89,3.15$ & 0.109 \\
\hline ET & 2.14 & $1.13,4.06$ & 0.019 \\
\hline CHT & 4.54 & $2.29,9.00$ & $<0.001$ \\
\hline No adjuvant therapy & 4.69 & $2.43,9.06$ & $<0.001$ \\
\hline Age (years) & 1.05 & $1.04,1.06$ & $<0.001$ \\
\hline \multicolumn{4}{|l|}{ Tumor size } \\
\hline pT1 & Reference & & \\
\hline pT2 & 1.53 & $1.27,1.84$ & $<0.001$ \\
\hline pT3 & 2.06 & $1.49,2.85$ & $<0.001$ \\
\hline pT4 & 2.51 & $1.92,3.27$ & $<0.001$ \\
\hline \multicolumn{4}{|l|}{ Nodal status } \\
\hline No & Reference & & \\
\hline N1 & 1.55 & $1.29,1.87$ & $<0.001$ \\
\hline $\mathrm{N} 2$ & 1.90 & $1.46,2.48$ & $<0.001$ \\
\hline N3 & 2.69 & $2.04,3.55$ & $<0.001$ \\
\hline \multicolumn{4}{|l|}{ Grading } \\
\hline G1 & Reference & & \\
\hline G2 & 1.29 & $0.99,1.68$ & 0.063 \\
\hline G3 & 2.00 & $1.49,2.68$ & $<0.001$ \\
\hline \multicolumn{4}{|l|}{ HER2/neu } \\
\hline Negative & Reference & & \\
\hline Positive & 1.00 & $0.81,1.23$ & 0.986 \\
\hline \multicolumn{4}{|l|}{ Menopausal status } \\
\hline Premenopausal & Reference & & \\
\hline Postmenopausal & 0.67 & $0.48,0.92$ & 0.012 \\
\hline
\end{tabular}

in premenopausal patients, get an additional CHT. This observation has already been made in a previous study of our group (Inwald et al. 2014). Another explanation might be incompliant long-term use of ET especially in postmenopausal patients (Demissie et al. 2001). It has been shown that the adherence to adjuvant therapy in clinical practice is relatively poor, with up to $50 \%$ of women not completing ET (Chlebowski et al. 2014). A study from an online breast cancer research registry showed that nonadherence among users was significantly associated with a lower financial status, a poorer relationship with the oncologist, and a prior switch in endocrine therapies (Stanton et al. 2014). However, low adherence to adjuvant ET increases the risk of death (Makubate et al. 2013). Nevertheless, there are some limitations of this population-based study: These data primarily cover subnational or regional districts and might not reflect the entire population. The regional data might not be representative of international data due to regional variances, e.g., risk factors or access to early screening. However, the strength of the data is that it reflects routine healthcare provisions. Consequently, these data can be used to analyze the structures of patient-centered care.

\section{Conclusions}

We conclude that analysis of HR in patients with early breast cancer achieved very high quality in recent years due to implementation of guidelines and control mechanisms. In line with current guidelines, the vast majority of HR-positive patients mostly received ET and this resulted in improved OS. Furthermore, our study showed differential effects of CHT and ET combination in premenopausal versus postmenopausal patients not previously described in a population-based cohort. In light of this positive finding, it is of major importance to track the minority of patients who did not receive appropriate therapy and to identify the reasons for this fatal deviation from current guidelines.

Acknowledgments The Tumor Center is funded and supported by the University of Regensburg, the Health Insurance Funds, and the regional hospitals and private doctor's practices. No special or additional funding was obtained for the present project. We acknowledge the support of the data managers at the Tumor Center Regensburg, particularly Kristina Vetter, Martina Käufl, Denise Lang, and Christine Glötzl. We thank Jennifer Dozier Ritter for language editing of the manuscript.

\section{Compliance with ethical standards}

Conflict of interest The authors declare that they have no conflict of interest.

Human and animal rights statement This article does not contain any studies with human participants or animals performed of any of the authors.

Open Access This article is distributed under the terms of the Creative Commons Attribution 4.0 International License (http://creativecommons.org/licenses/by/4.0/), which permits unrestricted use, distribution, and reproduction in any medium, provided you give appropriate credit to the original author(s) and the source, provide a link to the Creative Commons license, and indicate if changes were made.

\section{References}

Baum M, Budzar AU, Cuzick J, Forbes J, Houghton JH, Klijn JGM, Sahmoud T (2002) Anastrozole alone or in combination with tamoxifen versus tamoxifen alone for adjuvant treatment of postmenopausal women with early breast cancer: first results of the ATAC randomised trial. Lancet 359:2131-2139

Baum M, Hackshaw A, Houghton J, Rutqvist Fornander T, Nordenskjold B, Nicolucci A, Sainsbury R (2006) Adjuvant goserelin in pre-menopausal patients with early breast cancer: results from the ZIPP study. Eur J Cancer 42:895-904 
Chlebowski RT, Kim J, Haque R (2014) Adherence to endocrine therapy in breast cancer adjuvant and prevention settings. Cancer Prev Res (Phila) 7:378-387

Coombes RC, Hall E, Gibson LJ, Paridaens R, Jassem J, Delozier T, Jones SE, Alvarez I, Bertelli G, Ortmann O, Coates AS, Bajetta E, Dodwell D, Coleman RE, Fallowfield LJ, Mickiewicz E, Andersen J, Lønning PE, Cocconi G, Stewart A, Stuart N, Snowdon CF, Carpentieri M, Massimini G, Bliss JM, van de Velde C, Intergroup Exemestane Study (2004) A randomized trial of exemestane after two to three years of tamoxifen therapy in postmenopausal women with primary breast cancer. N Engl J Med 350:1081-1092

Cuzick J, Ambroisine L, Davidson N, Jakesz R, Kaufmann M, Regan M, Sainsbury R (2007) Use of luteinising-hormone-releasing hormone agonists as adjuvant treatment in premenopausal patients with hormone-receptor-positive breast cancer: a metaanalysis of individual patient data from randomised adjuvant trials. Lancet 369:1711-1723

Davies C, Pan H, Godwin J, Gray R, Arriagada R, Raina V, Abraham M, Alencar Medeiros, Hugo Victor, Badran A, Bonfill X, Bradbury J, Clarke M, Collins R, Davis SR, Delmestri A, Forbes JF, Haddad P, Hou M, Inbar M, Khaled H, Kielanowska J, Kwan W, Mathew BS, Mittra I, Muller B, Nicolucci A, Peralta O, Pernas F, Petruzelka L, Pienkowski T et al (2013) Long-term effects of continuing adjuvant tamoxifen to 10 years versus stopping at 5 years after diagnosis of oestrogen receptor-positive breast cancer: ATLAS, a randomised trial. Lancet 381:805-816

Demissie S, Silliman RA, Lash TL (2001) Adjuvant tamoxifen: predictors of use, side effects, and discontinuation in older women. J Clin Oncol 19:322-328

Dowsett M, Cuzick J, Ingle J, Coates A, Forbes J, Bliss J, Buyse M, Baum M, Buzdar A, Colleoni M, Coombes C, Snowdon C, Gnant M, Jakesz R, Kaufmann M, Boccardo F, Godwin J, Davies C, Peto R (2010) Meta-analysis of breast cancer outcomes in adjuvant trials of aromatase inhibitors versus tamoxifen. J Clin Oncol 28:509-518

Early Breast Cancer Trialists' Collaborative Group (EBCTCG) et al (2005) Effects of chemotherapy and hormonal therapy for early breast cancer on recurrence and 15-year survival: an overview of the randomised trials. Lancet 365:1687-1717

Early Breast Cancer Trialists' Collaborative Group (EBCTCG), Davies C, Godwin J, Gray R, Clarke M, Cutter D, Darby S, McGale P, Pan HC, Taylor C, Wang YC, Dowsett M, Ingle J, Peto R (2011) Relevance of breast cancer hormone receptors and other factors to the efficacy of adjuvant tamoxifen: patient-level meta-analysis of randomised trials. Lancet 378:771-784

Ejlertsen B, Jensen M, Mouridsen HT (2014) Excess mortality in postmenopausal high-risk women who only receive adjuvant endocrine therapy for estrogen receptor positive breast cancer. Acta Oncol 53:174-185

Friese CR, Pini TM, Li Y, Abrahamse PH, Graff JJ, Hamilton AS, Jagsi R, Janz NK, Hawley ST, Katz SJ, Griggs JJ (2013) Adjuvant endocrine therapy initiation and persistence in a diverse sample of patients with breast cancer. Breast Cancer Res Treat 138:931-939

Goss PE, Ingle JN, Martino S, Robert NJ, Muss HB, Piccart MJ, Castiglione M, Tu D, Shepherd LE, Pritchard KI, Livingston RB, Davidson NE, Norton L, Perez EA, Abrams JS, Therasse P, Palmer MJ, Pater JL (2003) A randomized trial of letrozole in postmenopausal women after five years of tamoxifen therapy for early-stage breast cancer. $\mathrm{N}$ Engl J Med 349:1793-1802

Hammond MEH, Hayes DF, Dowsett M, Allred DC, Hagerty KL, Badve S, Fitzgibbons PL, Francis G, Goldstein NS, Hayes M, Hicks DG, Lester S, Love R, Mangu PB, McShane L, Miller K, Osborne CK, Paik S, Perlmutter J, Rhodes A, Sasano H,
Schwartz JN, Sweep Fred C G, Taube S, Torlakovic EE, Valenstein P, Viale G, Visscher D, Wheeler T, Williams RB et al (2010) American Society of Clinical Oncology/College Of American Pathologists guideline recommendations for immunohistochemical testing of estrogen and progesterone receptors in breast cancer. J Clin Oncol 28:2784-2795

Inwald EC, Klinkhammer-Schalke M, Hofstädter F, Zeman F, Koller M, Gerstenhauer M, Ortmann O (2013) Ki-67 is a prognostic parameter in breast cancer patients: results of a large population-based cohort of a cancer registry. Breast Cancer Res Treat 139:539-552

Inwald EC, Ortmann O, Zeman F, Koller M, Hofstädter F, Gerstenhauer M, Klinkhammer-Schalke M (2014) Guideline concordant therapy prolongs survival in HER2-positive breast cancer patients: results from a large population-based cohort of a cancer registry. Biomed Res Int 2014:137304

Kolberg H, Lüftner D, Lux M, Maass N, Schütz F, Fasching P, Fehm T, Janni W, Kümmel S (2012) Breast Cancer 2012 - New Aspects. Geburtsh Frauenheilk 72:602-615

Kreienberg R, Albert U, Follmann M, Kopp IB, Kühn T, Wöckel A (2013) Interdisciplinary GoR level III guidelines for the diagnosis, therapy and follow-up care of breast cancer: short versionAWMF registry no.: 032-045OL AWMF-register-nummer: 032-045OL-Kurzversion 3.0, Juli 2012. Geburtshilfe Frauenheilkd 73:556-583

Lux M, Maass N, Schütz F, Schwidde I, Fasching P, Fehm T, Janni W, Kümmel S, Kolberg H, Lüftner D (2013) Breast cancer 2013: interpretation of new and known data. Geburtsh Frauenheilk 73:584-598

Makubate B, Donnan PT, Dewar JA, Thompson AM, McCowan C (2013) Cohort study of adherence to adjuvant endocrine therapy, breast cancer recurrence and mortality. Br J Cancer 108:1515-1524

Melcher C, Scholz C, Jäger B, Hagenbeck C, Rack B, Janni W (2012) Breast cancer: state of the art and new findings. Geburtsh Frauenheilk 72:215-224

Pagani O, Regan MM, Walley BA, Fleming GF, Colleoni M, Láng I, Gomez HL, Tondini C, Burstein HJ, Perez EA, Ciruelos E, Stearns V, Bonnefoi HR, Martino S, Geyer CE, Pinotti G, Puglisi F, Crivellari D, Ruhstaller T, Winer EP, Rabaglio-Poretti M, Maibach R, Ruepp B, Giobbie-Hurder A, Price KN, Bernhard J, Luo W, Ribi K, Viale G, Coates AS et al (2014) Adjuvant exemestane with ovarian suppression in premenopausal breast cancer. N Engl J Med 371:107-118

Petrelli F, Coinu A, Cabiddu M, Ghilardi M, Lonati V, Barni S (2013) Five or more years of adjuvant endocrine therapy in breast cancer: a meta-analysis of published randomised trials. Breast Cancer Res Treat 140:233-240

Prechtel K, Prechtel D (2001) Current standards for the diagnosis of breast carcinoma in routine practice. Pathologe 22:281-284

Pritchard KI, Bergh J, Burstein HJ (2012) Update of the oxford overview: new insight and perspectives in the era of personalized medicine. Am Soc Clin Oncol Educ Book 2012:71-79

Remmele W, Stegner HE (1987) Recommendation for uniform definition of an immunoreactive score (IRS) for immunohistochemical estrogen receptor detection (ER-ICA) in breast cancer tissue. Pathologe 8:138-140

Stanton AL, Petrie KJ, Partridge AH (2014) Contributors to nonadherence and nonpersistence with endocrine therapy in breast cancer survivors recruited from an online research registry. Breast Cancer Res Treat 145:525-534

Thürlimann B, Keshaviah A, Coates AS, Mouridsen H, Mauriac L, Forbes JF, Paridaens R, Castiglione-Gertsch M, Gelber RD, Rabaglio M, Smith I, Wardley A, Price KN, Goldhirsch A (2005) A comparison of letrozole and tamoxifen in postmenopausal women with early breast cancer. N Engl J Med 353:2747-2757 
Thürlimann B, Price KN, Gelber RD, Holmberg SB, Crivellari D, Colleoni M, Collins J, Forbes JF, Castiglione-Gertsch M, Coates AS, Goldhirsch A (2009) Is chemotherapy necessary for premenopausal women with lower-risk node-positive, endocrine responsive breast cancer? 10-year update of International Breast Cancer Study Group Trial 11-93. Breast Cancer Res Treat 113:137-144

Untch M, Gerber B, Harbeck N, Jackisch C, Marschner N, Möbus V, von Minckwitz G, Loibl S, Beckmann MW, Blohmer J, Costa S, Decker T, Diel I, Dimpfl T, Eiermann W, Fehm T, Friese K, Jänicke F, Janni W, Jonat W, Kiechle M, Köhler U, Lück H, Maass N, Possinger K, Rody A, Scharl A, Schneeweiss A,
Thomssen C, Wallwiener D et al (2013) 13th st. Gallen international breast cancer conference 2013: primary therapy of early breast cancer evidence, controversies, consensus-opinion of a german team of experts (zurich 2013). Breast Care (Basel) 8:221-229

Van Ewijk RJG, Schwentner L, Wöckel A, König J, Kreienberg R, Blettner M (2013) Trends in patient characteristics, treatment and survival in breast cancer in a non-selected retrospective clinical cohort study of 2,600 patients. Arch Gynecol Obstet 287:103-110 